\title{
Reseña de Sentencias del Tribunal Constitucional sobre la Administración Local y Autonómica que aparecen publicadas en el B.O.E. durante el tercer trimestre de 1993
}

\author{
Francisco Javier Fernández González \\ Profesor Titular de Derecho Administrativo \\ Universidad de Oviedo
}

SUMARIO: I. FUENTES. Legislación básica. II. REGIMEN ELECTORAL. III. DERECHO FUNDAMENTAL DE PETICIÓN. IV. BIENES PÚBLICOS. AGUAS. V. DERECHO PÚBLICO DE LA ECONOMIA: A) Agricultura y Ganadería. B) Comercio interior. C) Entidades de Crédito. D) Telecomunicaciones

\section{FUENTES. Legislación básica}

1. Conflicto positivo de competencia núm. 284/86, planteado por el Consejo Ejecutivo de la Generalidad de Cataluña frente a diversos artículos del RD 1945/1985, de 9 de octubre, por el que se regula la Hemodonación y los Bancos de Sangre. El TC entiende, por un lado, que los arts. 2.2 y 18.3, la Disp. Adic. primera y la Disp. final primera del citado $R D$ carecen de los requisitos formales necesarios para ser considerados normativa básica en la materia; pero, por otro lado, señala que el art. 3.1 del RD cae dentro del ámbito de lo legítimamente regulable como básico por el Estado.

«Para responder a la pretensión formulada por el Consejo Ejecutivo de la Generalidad fundado en la inadecuación del Real Decreto 1945/1985 para establecer bases de la Sanidad, ha de partirse de la doctrina ya expresada por este Tribunal... respecto de los requisitos derivados del reparto constitucional de competencias referidos al rango de las normas estatales que establezcan bases o normas básicas. Sin necesidad de reiterar afirmaciones que pueden encontrarse ya in extenso en otras Sentencias de este Tribunal, basta aquí señalar que hemos considerado, desde la STC 32/1981 (F.J. 5. ${ }^{\circ}$ ) que "las Cortes deberán establecer lo que haya de entenderse por básico", y que procede exigir "la condición for- 
mal que la 'norma básica' venga incluida en Ley votada en Cortes" (STC 69/1988, F.J. 6. ${ }^{\circ}$ ). Ahora bien, ello no excluye la posibilidad excepcional de que las normas básicas vengan fijadas mediante el uso, por el Gobierno, de la potestad reglamentaria.

Estas excepciones, en lo que aquí importa, son de dos tipos. Por un lado hemos afirmado que, en ausencia de legislación post-constitucional sobre una materia, el Gobierno podrá regular una materia básica cuando "de la legislación pre-constitucional pueda inferirse cuáles sean las bases de la materia en cuestión" (STC 32/1983, F.J. 2. ${ }^{\circ}$ ) aun cuando en tal caso "esa fijación de lo básico quedaría afectada de una cierta provisionalidad, y quedaría pendiente de que el legislador post-constitucional la confirmase o revocase" (STC 32/1983, ibidem). Por otra parte, cabe también una regulación reglamentaria de materias básicas, cuando ya se hayan dictado normas legales post-constitucionales definidoras de lo básico, si esa regulación resultara primeramente, "de una habilitación legal, y, en segundo lugar, si su rango reglamentario viniera justificado por tratarse de materias cuya naturaleza exigiera un tratamiento para el que las normas legales resultaran inadecuadas por sus mismas características" (STC 77/1985, F.J. 16. ${ }^{\circ}$ ).

Ahora bien, la licitud constitucional de la definición de las bases mediante una norma reglamentaria requiere además el cumplimiento de un tercer requisito; se trata de que se realice "con observancia de las garantías de certidumbre jurídica que sean necesarias para asegurar que las Comunidades Autónomas tengan posibilidad normal de conocer cuál es el marco básico al que deben someter sus competencias [...] de forma que es misión de este Tribunal procurar [...] que la definición de lo básico no quede a la libre disposición del Estado en evitación de que puedan dejarse sin contenido o inconstitucionalmente cercenadas las competencias autonómicas y velar porque el cierre del sistema no se mantenga en la ambigüedad permanente que supondría reconocer al Estado facultad para oponer sorpresivamente a las Comunidades Autónomas como norma básica, cualquier clase de precepto legal y reglamentario, al margen, de cuál sea su rango y estructura" (STC 69/1988, creando una línea jurisprudencial reiterada en las SsTC 182/1988, 227/1988, 248/1988, $15 / 1989$ y 35/1992); de manera que "lo que no es admisible constitucionalmente es que la norma pretendidamente básica con independencia ahora del rango normativo que tenga no concrete lo básico, sino por remisión a una posterior labor deductiva a desarrollar sobre la propia disposición o sobre cualesquiera otras, ya que con ello se crea un ámbito de inseguridad y confusión radicalmente incompatible con el sistema de distribución de competencias constitucionalmente estable- 
JURISPRUDENCLA

cido..." (STC 182/1988) y que "ha de atenderse, junto al concepto material de 'norma básica' a una elemental exigencia de seguridad jurídica, que impida calificar de básicos otros preceptos que aquéllos de los cuales esa naturaleza pueda inferirse sin dificultad" (STC 248/1988)» (vid. f.j. 4. ${ }^{\circ}$ ).

«Tras la aprobación de la Constitución, la Ley 30/1979, de 27 de octubre, vino a regular la extracción y transplantes de órganos, encomendando al Gobierno el desarrollo por vía reglamentaria de lo allí prevenido, y precisando (Disposición adicional segunda) que la Ley no sería de aplicación a la utilización terapéutica de sangre humana y sus derivados: pero que "su reglamentación se inspirará en los principios informadores de esta Ley".

A la vista de la evolución normativa expuesta, se desprende que la Ley de 27 de octubre de 1979 contenía una habilitación al Gobierno para reglamentar "de acuerdo con los principios informadores de esta Ley" la utilización terapéutica de la sangre humana y sus derivados. Se trata de una habilitación contenida en una norma post-constitucional, aunque anterior a la aprobación de los primeros Estatutos de Autonomía (Estatuto de Autonomía del País Vasco, L.O. 3/1979 y Estatuto de Autonomía de Cataluña, L.O. 4/1979, ambas de 18 de diciembre). Aun así, no ofrece duda la pretensión de la Ley de regular elementos básicos de la Sanidad, tanto por la naturaleza de las normas que contiene (que, como admite la misma demanda del Consejo Ejecutivo, fijan principios básicos como los de voluntariedad, gratuidad, información al donante, anonimato y otros) como por la referencia que hace a las Comunidades Autónomas a determinados efectos (art. 7.1), lo que muestra que el legislador tuvo en cuenta la previsible alteración de la estructura territorial del Estado, a la hora de formular principios básicos de la Sanidad. Tampoco surge duda alguna al afirmar que la naturaleza de la materia sobre la que versa justifica que se recurra para su adecuación a normas reglamentarias, en lugar de como mantiene la representación del Consejo Ejecutivo de la Generalidad mediante normas con rango de ley.

Sin embargo, la respuesta debe ser matizada si analizamos la citada habilitación desde la óptica de la certeza y seguridad que en el ejercicio de las competencias propias de las Comunidades Autónomas debe reunir toda operación de fijación normativa de las "bases" de una determinada materia en el sentido establecido por la STC 69/1988, al que ya nos hemos referido con anterioridad.

En efecto, es en primer lugar indiscutible que la Ley 27 de octubre de 1979 regula una materia distinta a la hemodonación; en concreto la extrac- 
ción y trasplante de órganos, y que la única referencia a la utilización terapéutica de la sangre humana, contenida en su Disposición adicional segunda, es precisamente y en su literalidad para declarar que "no será de aplicación a la utilización terapéutica de la sangre humana y sus derivados", es decir, para reconocer que la materia no está regulada en ella, ni en consecuencia, cabría añadir, en ninguna otra norma post-constitucional con rango de ley, para añadir, sin embargo, a continuación que "su reglamentación se inspirará en los principios informadores de esta Ley".

Es también evidente que tal habilitación reviste un grado de indeterminación e inconcreción que no permite considerarla un instrumento normativo suficiente para legitimar la fijación de bases en materia de hemodonación con carácter general y mediante normas reglamentarias. En efecto, la Ley se remite a los "principios informadores" contenidos en ella como canon o guía para la regulación reglamentaria de la hemodonación. Pero precisamente por referirse la Ley a una materia distinta y sólo relativamente conexa con la hemodonación, no son, con alguna precisión que después se hará, automáticamente y en bloque trasladables a esta última los criterios contenidos en la regulación legal (criterios que incluso en ocasiones resultan abiertamente incompatibles con las características de la hemodonación: por ejemplo, el art. 5 de la Ley exige la certeza de la muerte del paciente para realizar la extracción de órganos). Por ello, la norma no concreta suficientemente lo básico, sino que se hace necesaria una posterior labor conjetural, para la determinación de lo que puede resultar básico; lo que, como ya hemos señalado, resulta "radicalmente incompatible con el sistema de distribución de competencia constitucionalmente establecido" (STC 182/1988).

Aparece patente, pues, como punto de partida, la falta de concreción y ambigüedad de la referida habilitación, a los efectos de crear la necesaria seguridad jurídica para el ejercicio de las competencias de las Comunidades Autónomas. Ahora bien, y aun siendo así, no procede estimar sin más, como consecuencia, la falta de carácter básico de todos los preceptos que ahora se impugnan, sino que habrá que atender a sus concretos contenidos para determinar si, pese a los muy generales términos de la habilitación contenida en la Ley de 27 de octubre de 1979, así y todo, cabe inducir de ella criterios explícitos informadores que justifiquen el carácter básico de los preceptos reglamentarios (o de alguno de ellos) que ahora se impugnan.

Pues bien, a este respecto es preciso distinguir, de los preceptos objeto de conflicto, por un lado el art. 3.1 del Real Decreto 1.945/1985 $\mathrm{y}$, por otro, el resto de las disposiciones que ahora se impugnan. 
El art. 3.1 establece el carácter voluntario y gratuito de la donación de sangre o de alguno de sus componentes, como norma general. Y este mandato no puede considerarse desvinculado o desligado de las previsiones explícitas de la Ley 30/1979, que establecía también la gratuidad como regla general, respecto de la donación de órganos (art. 2). El carácter básico de esta previsión, como criterio manifiesto y de aplicación general, justifica suficientemente que, por disposición reglamentaria, se aplique igualmente a la donación de sangre: en este supuesto, no hay dificultad para estimar que cabe aplicar a la hemodonación, sin dificultad, un "criterio informador" manifiesto en la Ley 30/1979.

Sentado este extremo, ha de señalarse que, respecto del art. 3.1, lo que el escrito de planteamiento de conflicto impugna expresamente es la previsión de que la hemodonación "deba realizarse bajo control o vigilancia médica y cumpliendo los requisitos, condiciones mínimas y garantías que se señalan en el presente Real Decreto y en las normas de su desarrollo». En cuanto a la necesidad de vigilancia médica, se trata de un criterio que se desprende sin dificultad de la Ley 30/1979 como criterio básico (arts. 3,4 y 6 ), por lo que no puede estimarse que la norma reglamentaria ahora impugnada se exceda, desde la perspectiva del reparto competencial, de la habilitación contenida en la citada Ley. Finalmente, la remisión a "las condiciones y garantías que se señalan en el presente Decreto" sólo incluirá un exceso competencial en cuanto se refiera a disposiciones viciadas de incompetencia: por lo que, considerada en sí misma, no puede estimarse que se haya dictado ultra vires de las competencias del Estado. A resultas de todo ello, debe concluirse que el art. 3.1 cae dentro del ámbito de lo legítimamente regulable como básico por el Estado.

Distinto es el caso de los demás preceptos impugnados. En ellos se regulan aspectos de la hemodonación y hemodiálisis a los que no resultan, en forma clara y directa, aplicables los criterios de la citada Ley, que versa, como se dijo, sobre materia distinta: fijación de patrones y requisitos por el Ministerio de Sanidad (art. 2.2), regulación general de una Red nacional de Bancos de Sangre (art. 18.3), autorización del Ministerio de Sanidad y Consumo a determinados Centros para proseguir la práctica de la plasmofíresis (Disposición adicional primera) y autorización para tal práctica mediante gratificación económica (Disposición final primera). Se trata de materias sobre las que no hace referencia alguna, ni siquiera lejanamente, la Ley 30/1979. Por tanto, esos preceptos introducen una regulación con pretensión de ostentar carácter básico, que ni tiene rango de Ley, ni viene a fundamentarse en una habilitación legal suficiente para cumplir las condiciones exigibles a la normativa básica, según la doctrina de este Tribunal arriba expuesta. 
Con relación a estos preceptos, pues, no cabe estimar que la Ley 30/1979 reúna las condiciones exigibles para que pueda ser considerada norma básica en la materia; y en consecuencia menos aún lo serán los artículos impugnados del Real Decreto, que sobre una inconcreta e insuficiente habilitación pretenden la determinación de las bases, más aún si tenemos en cuenta que alguno de ellos (en particular, 2.2, 18.3 y Disposición adicional tercera) contienen a su vez remisiones a posteriores Ordenes Ministeriales, lo que a todas luces supone que el Estado se reserve una suerte de facultad de cierre del sistema de reparto competencial, vulnerando el principio de certidumbre jurídica que debe regir el esquema de distribución de competencias.

Procede, por tanto, con respecto a estos artículos declarar que no ostentan las necesarias garantías formales, que son exigibles a una norma que pretende delimitar una competencia autonómica mediante el establecimiento de las bases de la materia y, en consecuencia, negar su carácter de norma básica, sin perjuicio de su carácter supletorio, y del reconocimiento, expresamente aceptado en el planteamiento del conflicto, de que el Estado es la instancia competente para, mediante el instrumento formal oportuno y con la concreción y seguridad jurídica necesarias, fijar las bases de actuación del conjunto de las Administraciones Públicas en la materia» (vid. ff.jj. 5 a 11).

Fallo: $1 .^{\circ}$ Declarar que los arts. 2.2 y 18.3 , la Disp. Adic. primera y la Disp. final primera del RD impugnado, carecen de los requisitos formales necesarios para ser considerados normativa básica en la materia y, en consecuencia, no resultan de aplicación en la CA recurrente más que con carácter supletorio.

2. ${ }^{\circ}$ Declarar que pertenece al Estado la competencia ejercida en el art. 3.1 del $\mathrm{RD}$ impugnado.

(Sentencia n. ${ }^{\circ}$ 203/1993, de 17 de junio. Pleno. BOE 19-7-1993. L. López Guerra).

\section{REGIMEN ELECTORAL}

1. Recurso de amparo electoral núm. 1.625/93, interpuesto contra la Sentencia de 14 de mayo de 1993 de la Sala de lo Contencioso-Administrativo del Tribunal Superior de Justicia de Navarra, recaída en el recurso contencioso-electoral núm. 187/1993, interpuesto por el Partido Socialista de Navarra (PSN/PSOE). La Sentencia impugnada 
JURISPRUDENCIA

declaró nulo el acuerdo del Pleno del Ayuntamiento de Barañaín, de 25 de febrero de 1993, que consideró candidato a Alcalde como cabeza de lista del PSN/PSOE al ahora recurrente en amparo y proclamó al mismo como Alcalde de la citada corporación, pese a que habia abandonado por propia voluntad el Grupo Municipal Socialista. El TC deniega el amparo y entiende que la mencionada Sentencia no vulnera el art. 23.2 CE puesto que el demandante de amparo no puede ser considerado "cabeza de lista" de un Grupo Municipal que había abandonado.

«Del mismo modo que en el momento inicial subsiguiente a la constitución del Ayuntamiento el protagonismo de la elección corresponde esencialmente a las listas, aunque personalizado en sus cabezas de lista, en los supuestos de vacantes producidas a lo largo del mandato municipal el protagonismo sólo puede corresponder a los Grupos Municipales en los que orgánicamente se han traducido las listas, de tal modo que cada Grupo Municipal de los así formados debe tener la posibilidad de presentar un candidato a Alcalde. Sería, en efecto, contrario a toda la lógica del sistema que el abandono del Grupo Municipal por quien fue cabeza de lista tuviese la consecuencia de privar a ese grupo, acaso mayoritario, de la posibilidad de presentar un candidato. La cabecera de lista, en definitiva, no es una cualidad personal que siga al que en su momento fue cabeza de lista (o siguiente al mismo) "allí donde vaya" y al margen de que continúe o no encabezando alguna cosa, sino únicamente un elemento de personalización de las listas (y después de los Grupos Municipales), en todo caso subordinado a la lógica de un sistema electoral en el que el protagonismo básico corresponde a unas candidaturas que son colectivas o colegiadas. De ahí que la autoexclusión del Grupo Municipal deba considerarse equivalente a la autoexclusión de la lista de origen.

En este sentido conviene comenzar declarando cómo es, en primer lugar incontrovertible que el recurrente expresó de manera fehaciente su intención de abandonar las listas del PSN/PSOE... No hay duda alguna, como acertadamente razona la Sentencia impugnada, que se trata de un acto libre, plenamente voluntario y formalmente realizado en ejercicio de sus derechos constitucionales, acto que como tal adquiere plena eficacia desde su formalización. Se trata, como señala el Ministerio Fiscal en sus alegaciones, de un acto recepticio y unilateral que produce plena eficacia con su presentación en la Secretaría del Ayuntamiento (art. 24.1 ROF) sin necesidad de su aceptación por el Pleno ya que el art. 25 ROF sólo habla de "dar cuenta al Pleno" requisito al que no pueden anudarse efectos constitutivos. Por otra parte, y 
en este mismo sentido, este Tribunal ha tenido ocasión de pronunciarse sobre los efectos de la renuncia al cargo de concejales, declarando al respecto (Auto TC 7/1984), que no existe limitación alguna en cuanto a la posibilidad de renuncia en cualquier momento, sin que sea necesario para que surta efectos que la misma sea aceptada por los correspondientes Ayuntamientos, configurándose como una declaración de voluntad que surte efectos automáticos, igual que en los supuestos de fallecimiento o incapacidad (...)

Así pues, y en definitiva, los recurrentes abandonaron por su propia voluntad el Grupo Municipal Socialista, y no puede considerarse que se ha producido su reingreso en el mismo ante la expresa y lícita negativa de aceptación de quien es su único componente, y de los órganos representativos del partido.

Ahora bien, y llegando con ello a la resolución final del recurso, es evidente que quien, por las razones expuestas, no forma parte de la lista de un grupo político de un Ayuntamiento no puede en forma alguna ser considerado "cabeza de lista" de ese mismo grupo a los efectos del art. 196 de la LOREG, y que en ese sentido ningún reproche constitucional puede merecer una Sentencia que se limita a constatar razonadamente este hecho, anulando con toda corrección el Acuerdo municipal que decide lo contrario" (vid. f.j. $5^{\circ}$ ).

Fallo: Desestimar el recurso de amparo.

(Sentencia n. ${ }^{\circ}$ 185/1993, de 31 de mayo. Sala Primera. BOE 5-7-1993. C. de la Vega Benayas).

\section{DERECHO FUNDAMENTAL DE PETICIÓN}

1. Recurso de amparo núm. 862/1990 contra el Parlamento de Canarias por falta de respuesta a una petición formulada por un ciudadano. El Tribunal Constitucional entiende que se ha vulnerado el derecho fundamental de petición del artículo 29.1 de la Constitución y, en consecuencia, otorga el amparo.

"La petición en que consiste el derecho en cuestión tiene un mucho de instrumento para la participación ciudadana, aun cuando lo sea por vía de sugerencia, y algo del ejercicio de la libertad de expresión como posibilidad de opinar. Concepto residual, pero no residuo histórico, cumple una función reconocida constitucionalmente, para individualizar la cual 
quizá sea más expresiva una delimitación negativa. En tal aspecto excluye cualquier pretensión con fundamento en la alegación de un derecho subjetivo o un interés legítimo especialmente protegido, incluso mediante la acción popular en el proceso penal o la acción pública en el contencioso-contable o en el ámbito del urbanismo. La petición en el sentido estricto que aquí interesa no es una reclamación en la vía administrativa, ni una demanda o un recurso en la judicial, como tampoco una denuncia, en la acepción de la palabra ofrecida por la LECrim. O las reguladoras de la potestad sancionadora de la Administración en sus diversos sectores. La petición, en suma, vista ahora desde su anverso, puede incorporar una sugerencia o una información, una iniciativa, "expresando súplicas o quejas", pero en cualquier caso ha de referirse a decisiones discrecionales o graciables (STC 161/1988), sirviendo a veces para poner en marcha ciertas actuaciones institucionales, como la del Defensor del Pueblo o el recurso de inconstitucionalidad de las Leyes [arts. 54 y 161.1 a) CE], sin cauce propio jurisdiccional o administrativo, por no incorporar una exigencia vinculante para el destinatario» (vid. f.j. 1. ${ }^{\circ}$ ).

"Lo dicho ya pone en suerte la incógnita en que radica el problema tal y como fue planteado desde su principio, que consiste en ponderar el significado y extraer los efectos de la inactividad del Parlamento de Canarias, una vez recibida la petición a que este proceso se contrae. Conviene anticipar, al respecto, que el contenido de este derecho como tal es mínimo y se agota en la mera posibilidad de ejercitarlo, formulando la solicitud sin que de ello pueda derivarse perjuicio alguno al interesado, garantía o cautela que está en el origen histórico de este derecho y ha llegado a nuestros días. Ahora bien, hoy el contenido comprende algo más, aun cuando no mucho más, e incluye la exigencia de que el escrito al cual se incorpore la petición sea admitido, le dé el curso debido o se reexpida al órgano competente si no lo fuera el receptor y se tome en consideración. Desde la perspectiva del destinatario, se configuran dos obligaciones, una al principio, exteriorizar el hecho de la recepción, y otra al final, comunicar al interesado la resolución que se adopte (artículos 6.2 y 11.3 Ley reguladora), sin que ello "incluya el derecho a obtener respuesta favorable a lo solicitado" (STC 161/1988 y en el mismo sentido ATC 749/1985). En este grupo normativo hay que integrar el propio Reglamento del Parlamento de Canarias, cuyo artículo 46 sigue las directrices de la norma estatal. Es obligación de la Comisión ad hoc "examinar cada petición y acordar su remisión al órgano competente" o su archivo, pero en cualquier caso "se acusará recibo" y se "comunicará al peticionario el acuerdo adoptado". 
El relato de lo acaecido, a la luz de las normas que conforman el régimen jurídico de este derecho fundamental también expuestas,pone de manifiesto que en el caso concreto enjuiciado aquí, ha sido ejercido con toda pulcritud, un talante constructivo y un respeto hacia la institución al cual ella no ha correspondido ni siquiera cumpliendo el deber de acusar recibo al ciudadano en ninguna de las dos ocasiones, la segunda como recordatorio de la inicial, que se dirigió a la Comisión por escrito. La pasividad del órgano receptor ha sido absoluta, privando a la Cámara de todo conocimiento al respecto, incluso de la existencia de la petición y por supuesto de su contenido, sin explicación alguna no sólo al interesado pero ni siquiera interna. Los escritos respectivos no han merecido atención alguna, sin que tampoco se reenviaran a otros destinatarios, como podía serlo el Gobierno de la Nación o se canalizaran "a través del Diputado Común o del Defensor del Pueblo", según permite el precepto del Reglamento parlamentario donde se regula este derecho, más arriba citado. En fin, mal podía cumplirse la obligación de notificar la decisión tomada al respecto si la paralización fue completa desde el principio.

Está claro después de lo dicho que la Comisión de Peticiones del Parlamento de Canarias ha desconocido el derecho de petición ejercitado por el hoy demandante. Y no se diga que fue satisfecho por el Defensor Común canario, a quien se había dirigido el peticionario ante el silencio de la Comisión parlamentaria. Una y otra petición eran manifestaciones concretas de un mismo derecho abstracto, distintas e individualizables por su diferente destinatario, aun cuando coincidiera la cuestión planteada. La contestación a una no suple ni impide la respuesta a la otra, que sigue esperando y por tanto carece de relevancia en este proceso, cuya pretensión consiste en que se restaure la lesión que la inactividad del receptor ha producido al derecho de petición ejercido correctamente en su día. En tal sentido ha de ser amparado el peticionario, a quien se ha de reconocer el derecho a que el Parlamento Canario dé a su petición el curso previsto en el art. 46 de su Reglamento" (vid. ff.jj. $2 .^{\circ}$ y 3..$^{\circ}$ ).

Fallo: Estimar el recurso de amparo y, en consecuencia:

$1 .^{\circ}$ Reconocer la vulneración del art. 29.1 de la CE provocada por la omisión de toda respuesta por parte del Parlamento Canario a la petición dirigida por el recurrente.

2. ${ }^{\circ}$ Reconocer, como medida de restablecimiento, el derecho a que su petición sea tramitada conforme a la regulación del Reglamento del Parlamento Canario, incluyendo la obtención de "un acuse de recibo", así como que se le comunique el Acuerdo adoptado. 
JURISPRUDENCIA

(Sentencia $n .^{\circ}$ 242/1993, de 14 de julio. Sala Primera. BOE 12-8-1993. R. de Mendizábal Allende).

\section{BIENES PÚBLICOS. AGUAS}

1. Conflicto positivo de competencia núm. 1.107/86, planteado por el Consejo de Gobierno del Principado de Asturias, frente a la Resolución de la Dirección General de Obras Hidráulicas, de 7 de mayo de 1986, por la que se hace público el otorgamiento de una concesión de aprovechamiento de agua de los ríos Ponga, Sella y Dobra, en el término municipal de Ponga, con destino a fuerza motriz. El Tribunal Constitucional declara que corresponde a la Comunidad Autónoma del Principado de Asturias la competencia de emitir el informe de pesca fluvial previo al otorgamiento de la concesión del aprovechamiento hidráulico.

«El único modo de garantizar el ejercicio de la competencia autonómica sobre pesca fluvial y los ecosistemas en los que ésta se desarrolla estriba en que la intervención autonómica en el procedimiento de otorgamiento de concesiones de aprovechamientos hidroeléctricos preceda al acto de otorgamiento. Concretamente, a tenor de la legislación vigente, esa garantía radica en que los informes preceptivos sobre preservación de los recursos piscícolas y ecosistemas fluviales sean previos al otorgamiento de las referidas concesiones. De este modo al otorgar las concesiones podrá imponerse a las mismas el cumplimiento de las condiciones fijadas por la Comunidad Autónoma competente (pasos de diques o presas, caudales mínimos de agua, etc...), en orden a asegurar que los aprovechamientos de agua no pongan en peligro la riqueza piscícola y los ecosistemas en los que se desarrolla. Esto ha de ser así, puesto que la concesión es el acto administrativo que permite el acceso de una persona física o jurídica al uso privativo de un bien de dominio público [art. 57 de la Ley 29/1985, de 2 de agosto, de Aguas, en relación con el art. 22.a) sobre las competencias de los Organismos de cuenca] y es el acto por el que el concesionario se obliga a prestar un resultado satisfaciendo unos determinados requisitos y condicionamientos técnicos como hemos recordado, en un contexto distinto, en la reciente STC 108/1993; de manera que se establece a partir del otorgamiento una peculiar relación de colaboración entre la Administración concedente y el concesionario en el ámbito que la concesión tenga por objeto. Del mismo modo, es razonable pensar que los previsibles costes, perjuicios o limitaciones que al titular de un aprovechamiento de agua y a sus intereses privados se deriven del interés general en el mantenimiento de las 
especies, deban ser conocidos y convenientemente evaluados en el momento del previo otorgamiento de la concesión y a la luz de las condiciones que a las mismas se impongan, con el fin de que puedan cohonestarse las competencias estatal y autonómica que en este tema se entremezclan y los intereses privado y generales que concurren.

De hecho, como hemos apuntado anteriormente, en la legislación vigente hoy al dictar la Resolución controvertida, la intervención autonómica ex. art. 10.1, h) E.A.A., a través de los preceptivos informes, se concibe como previa al otorgamiento de las concesiones. Aquí sólo cabe reiterar que este carácter previo es una exigencia derivada no sólo de la referida legislación, sino del recto entendimiento del alcance que las competencias implicadas tienen en el bloque de la constitucionalidad. No resulta, pues, atendible la pretensión del Estado de excepcionar para el caso que aquí nos ocupa el carácter previo de la intervención autonómica.

No puede ser ajeno a esta valoración constitucional de la cuestión analizada el dato, destacado por este Tribunal en varias ocasiones (entre otras, SsTC 227/1988 y 66/1991), de que la protección de la pesca y los ecosistemas fluviales constituye un fin constitucionalmente legítimo al que todos los poderes públicos deben atender en virtud de lo establecido en el art. 45.2 de la Constitución que les encomienda la tarea de velar "por la utilización racional de todos los recursos naturales", precepto que, según ha establecido este Tribunal entraña una limitación para el derecho a la propiedad (STC 227/1988).

En suma, tanto en los supuestos de otorgamiento de nuevas concesiones como en los de modificaciones de las condiciones de los aprovechamientos por la realización de nuevas obras según los proyectos técnicos presentados o por el incremento de los caudales derivados, la garantía de la competencia autonómica recogida en el art. 10.1, h) del Estatuto de Autonomía para Asturias requiere de la previa remisión al Estado de los preceptivos informes, por parte de los órganos correspondientes de la Comunidad Autónoma, sobre la situación de la riqueza pesquera y el daño previsible en los ecosistemas a resultas de los aprovechamientos hidráulicos.

En cuanto a la pretendida posibilidad de sustituir la intervención autonómica por el informe sobre pesca fluvial emitido por la Administración estatal el 5 de abril de 1968, debe advertirse que este Tribunal, desde fechas muy tempranas, estableció que las Comunidades Autónomas adquieren la titularidad de sus competencias por obra de 
JURISPRUDENCIA

los respectivos Estatutos de Autonomía y que esta "atribución ipso iure de competencia debe entenderse como posibilidad de ejercicio inmediato", salvo en aquellos supuestos en los que para poder hacer efectivo ese ejercicio resulta "necesario e imprescindible" el traspaso de servicios. En estos casos "es constitucionalmente lícito el ejercicio de las competencias por el Estado mientras los servicios no son transferidos" (SsTC $25 / 1983,113 / 1983,125 / 1983,155 / 1990$, etc.). No obstante, efectuados los traspasos de servicios debe entenderse que la posibilidad de ejercicio de las competencias autonómicas se produce de forma inmediata sin que, salvo que existan regímenes transitorios específicos y explícitos, la plena aplicación de la nueva estructura territorial del Estado diseñada por la Constitución y los Estatutos pueda quedar supeditada a circunstancias externas como, en este caso, a la libre decisión de los organismos administrativos encargados de tramitar las concesiones, con el riesgo de que esa aplicación se dilate indefinidamente en el tiempo, como lo prueban los más de veintiséis años transcurridos en la tramitación de la concesión objeto del presente conflicto. En suma, desde la entrada en vigor del Estatuto de Autonomía y, muy especialmente, desde la entrada en vigor de los correspondientes Decretos de traspasos, es la Comunidad Autónoma la que debe valorar políticamente las exigencias de conservación de la riqueza piscícola de los ríos que transcurren por su territorio, sin que esta valoración pueda ser sustituida por la de otros entes.

Para concluir este razonamiento basta constatar que, como ambas partes reconocen, en el caso que nos ocupa la Comunidad Autónoma no pudo ejercer su competencia sobre pesca fluvial con carácter previo al otorgamiento de la concesión de aprovechamiento hidráulico mediante la Resolución de 7 de mayo de 1986. El Estado al otorgar esta concesión sin el previo informe de la Comunidad Autónoma desconoció, pues, la referida competencia autonómica, con lo que debe anularse la citada Resolución al efecto de que la Comunidad actora pueda ejercer su competencia de acuerdo con el alcance que la misma tiene en el bloque de la constitucionalidad" (vid. ff.jj. $4 .^{\circ}, 5^{\circ}$ y $6 .^{\circ}$ ).

Fallo: $1 .^{\circ}$ Declarar que corresponde a la Comunidad Autónoma de Asturias la competencia para emitir el informe sobre pesca fluvial previo al otorgamiento de la concesión del aprovechamiento hidráulico.

2. Anular la Resolución de 7 de marzo de 1986, de la Dirección General de Obras Públicas.

(Sentencia $n .^{\circ}$ 243/1993, de 15 de julio. Pleno 12-8-1993. D. Viver PiSunyer). 


\section{DERECHO PÚBLICO DE LA ECONOMÍA}

\section{A) Agricultura y ganadería}

1. Recurso de inconstitucionalidad núm. 887/86, promovido por 50 Senadores contra la Ley 1/1986, de 2 de mayo, de la Asamblea de Extremadura, sobre la Dehesa en Extremadura. El TC desestima el recurso en base a los argumentos expresados en la STC 37/1987 relativa a la Ley del Parlamento de Andalucía 8/1984, de 3 de julio, de Reforma Agraria.

«El presente recurso de inconstitucionalidad, dirigido contra diversos preceptos de la Ley de la Asamblea de Extremadura 1/1986, de 2 de mayo, de regulación de las Dehesas, guarda gran semejanza con el que el mismo Senador en su condición de comisionado de otros Senadores también planteó contra determinados artículos de la Ley del Parlamento de Andalucía 8/1984, de 3 de julio, de Reforma Agraria, recurso de inconstitucionalidad que tramitado con el núm. 685/1984 fue resuelto por la Sentencia del Pleno de este Tribunal 37/1987, de 26 de marzo.

Si se advierte esta circunstancia desde el principio es porque la respuesta que ahora deba darse a la impugnación del art. 20, de una parte, y de los arts. 21 a 29, de la otra, todos de la Ley extremeña de regulación de las Dehesas se encuentra ya prácticamente determinada por la doctrina contenida en la referida STC 37/1987» (vid. f.j. $1^{\circ}$ ).

"Dado que el artículo 20 de la Ley extremeña se limita a establecer que "la calificación de una dehesa en deficiente aprovechamiento (...) implicará el reconocimiento del incumplimiento de la función social de la propiedad y dará lugar (...), en su caso, por interés social, a la expropiación en uso o expropiación forzosa de la misma", es obvio que con tal previsión no se proceda a crear un nuevo supuesto de expropiación distinto de los establecidos por la legislación estatal —en concreto, por la Ley de Fincas Manifiestamente Mejorables-, sino que viene a definirse y concretarse la causa expropiandi en las materias de agricultura y ganadería que han sido atribuidas a la competencia de la C.A. de Extremadura (art. 7.1.6 de su EA), sin perjuicio, además, de que, de manera específica y singularizada, el art. 6.2.d) del mismo Estatuto ha encomendado a las instituciones de la C.A. de Extremadura, dentro del marco de su competencia, ejercer sus poderes - y entre ellos, por tanto, el expropiatorio (art. 50 b)- - con el objetivo básico de acometer una Reforma Agraria, "entendida como la transformación, modernización y 
desarrollo de las estructuras agrarias en cuanto elemento esencial para una política de desarrollo, fomento del empleo y corrección de desequilibrios territoriales dentro de Extremadura".

Junto a ello, el respeto íntegro de las garantías expropiatorias de carácter patrimonial y procedimental previstas por la legislación estatal, una vez que la Ley extremeña cuestionada guarda sobre este particular absoluto silencio, confirma definitivamente la adecuación del precepto recurrido al orden constitucional de distribución de competencias en la materia de expropiación forzosa" (vid. f.j. $2^{\circ}$ ).

«También se alega por los recurrentes que con la Ley que impugnan, el régimen de propiedad sobre fincas rústicas de más de 100 hectáreas dedicadas a explotaciones ganaderas no será el mismo en Extremadura que en otras partes del territorio nacional, infringiéndose así el principio de tratamiento uniforme que, con carácter exclusivo de acuerdo con lo dispuesto por el art. 149.1.1 de la Constitución, corresponde al Estado fijar para garantizar la igualdad de todos los españoles.

Sin embargo, una vez más el reproche formulado resulta coincidente con el que motivó que en la STC 37/1987, fundamentos jurídicos $9 .^{\circ}$ y 10 se dijera -y ahora se reitera más resumidamente- que el principio de igualdad no impone ni que todas las Comunidades Autónomas ostenten las mismas competencias, ni menos aún que tengan que ejercerlas de una determinada manera o con un contenido o resultados prácticamente semejantes (...) La objeción planteada queda desprovista de fundamento, una vez que, más allá de la denunciada falta de uniformidad en la manera que los recurrentes la entienden, en forma alguna cabe apreciar que la ley extremeña sea incompatible con esa igualdad de las posiciones jurídicas fundamentales de los ciudadanos en relación concreta, en este caso, con el ejercicio de los derechos y correlativos deberes patrimoniales que garantiza el art. 33 de la Constitución» (vid. f.j. $3 .^{\circ}$ ).

«Por último se impugnan los arts. 21 y 29 relativos al llamado "Impuesto de dehesas calificadas en deficiente aprovechamiento". La regulación de este impuesto viene a coincidir en sus elementos caracterizadores con la red del "Impuesto sobre Tierras Infrautilizadas" establecido por la Ley andaluza de Reforma Agraria y los motivos de inconstitucionalidad ahora alegados son también coincidentes con los que fundaran el recurso de inconstitucionalidad interpuesto contra el establecimiento del impuesto andaluz. Una vez más, por tanto, la doctrina de la STC 37/1987, fundamento jurídicos 12 y 14, es reproducible en su integridad para la resolución de la impugnación efectuada» (vid. f.j. $4 .^{\circ}$ ). 
Fallo: Desestimar el recurso de amparo de inconstitucionalidad.

(Sentencia n. ${ }^{\circ}$ 186/1993, de 7 de junio. Pleno. BOE 5-7-1993. F. García-Mon y González-Regueral.

\section{B) Comercio interior}

1. Recursos de inconstitucionalidad núms. $418 / 87$ y 421/87, y cuestiones de inconstitucionalidad núms. 1.902/91 y 1.904/91, acumulados, promovidos, el primero por 57 Diputados del Congreso contra los arts. 3, 4, 9, 13.3, 17 y 43.2 a) de la Ley de la Generalidad Valenciana 8/1986, de 29 de diciembre, de Ordenación del Comercio y Superficies Comerciales; el segundo, interpuesto por el Presidente del Gobierno de la Nación, contra el artículo 9 de dicha Ley; y las cuestiones planteadas, ambas, respecto al citado artículo 9 de la mencionada Ley por la Sección Segunda de la Sala de lo Contencioso-Administrativo del Tribunal Superior de Justicia de la Comunidad Valenciana. El Tribunal Constitucional estima parcialmente las pretensiones y declara la inconstitucionalidad y consiguiente nulidad del artículo 9, relativo a los horarios comerciales, y un inciso del párrafo primero del art. 4.1 de la Ley Valenciana 8/1986.

«Dentro del Título Primero de la Ley valenciana 8/1986, sobre el "Régimen administrativo de la actividad comercial", el art. 9 constituye la única disposición del Cap. II, relativo a los "horarios comerciales". Tras remitir al reglamento la regulación de esta materia, dicho precepto determina que "La apertura semanal máxima será de 60 h., considerándose inhábiles los domingos y festivos", aunque "podrán autorizarse horarios y días excepcionales al régimen general establecido". Ahora bien, con anterioridad al precepto autonómico, el RDL 2/1985, de 30 de Abril, de medidas de política económica, dispuso en su art. 5.1. que "El horario de apertura y cierre de establecimientos comerciales de venta y distribución de mercancías o de prestación de servicios al público, así como el número de días y horas de actividad semanal de los mismos, serán de libre fijación por las Empresas en todo el territorio del Estado, sin perjuicio de las competencias de las CC.AA. en los términos que establezcan sus respectivos EE.AA.». Es la existencia respecto a una misma materia, el régimen de los horarios comerciales, de la norma estatal y de la norma autonómica, lo que suscita las cuestiones objeto del presente proceso constitucional» (vid. f.j. $10^{\circ}$ ).

«El Estado se amparó en su competencia sobre ordenación de la actividad económica general que resulta tanto de la $\mathrm{CE}$ como del propio EA 
JURISPRUDENCIA

de la Comunidad Valenciana para dictar el art. 5.1 ${ }^{\circ}$ RDL 2/1985, de 30 de Abril, y siendo incompatible la norma estatal, de carácter básico, sobre libertad de horarios comerciales, con las restricciones en esta materia introducidas posteriormente por la Comunidad Valenciana en los dos primeros párrafos del art. 9 L. 8/1986, este precepto debe ser declarado inconstitucional y consiguientemente nulo en cuanto fija en $60 \mathrm{~h}$. la apertura semanal máxima de los establecimientos comerciales, declara inhábiles los domingos y festivos y prevé la autorización de horarios y días excepcionales al régimen general establecido. Asimismo, dada su conexión con los párrafos precedentes, procede declarar la inconstitucionalidad del inciso del último párrafo del art. 9 de la Ley 8/1986 en el que se dispone que "lo establecido en los párrafos anteriores en ningún caso podrá perjudicar los derechos reconocidos al trabajador por la legislación laboral vigente"; pronunciamiento que hace innecesario entrar en los motivos de la impugnación de este precepto aducidos por el Comisionado de los Diputados" (vid. f.j. $4^{\circ}{ }^{\circ}$ ).

«De otra parte, el Comisionado de los Diputados recurrentes ha sostenido en relación con el art. $4.1 .^{\circ}$, in fine, que este precepto entraña una absoluta discrecionalidad, desconociendo las garantías de legalidad, seguridad jurídica e interdicción de la arbitrariedad del art. $9 \mathrm{CE}$. Al respecto, ha de tenerse en cuenta que el art. $4.1^{\circ}$, condiciona el ejercicio de la actividad profesional al cumplimiento de los requisitos antes considerados y de "los que, en su caso, se establezcan reglamentariamente". Del tenor literal de este precepto se desprende, pues, que dicho apdo. $1 .^{\circ}$ opera una remisión en blanco al reglamento para la introducción de nuevos requisitos no expresamente previstos en la Ley 8/1986 de la Generalidad Valenciana, ya que ésta no contiene previsión alguna sobre cuáles han de establecerse en el futuro; por lo que dicho precepto claramente vulnera las exigencias constitucionales de legalidad, pues como se ha dicho por este Tribunal, dicho principio "no excluye, ciertamente, la posibilidad de que las leyes contengan remisiones a normas reglamentarias, pero sí que tales remisiones hagan posible una regulación independiente y no claramente subordinada a la Ley, lo que supondría una degradación de la reserva formulada por la CE en favor del legislador" (SsTC 83/1984, 99/1987 y 178/1989, entre otras). Procede, pues, declarar su inconstitucionalidad y consiguiente nulidad por contradicción con lo dispuesto en el art. 9.3. ${ }^{\circ} \mathrm{CE}$ ( $\left(v i d\right.$. f.j. $\left.6 .^{\circ}\right)$.

Fallo: Estimar parcialmente el recurso de inconstitucionalidad núm. $418 / 1987$ y en su totalidad el recurso de inconstitucionalidad núm. 421/1987, así como las cuestiones de inconstitucionalidad núms. $1.902 / 1991$ y $1.904 / 1991, y$, en consecuencia: 
1..$^{\circ}$ Declarar la inconstitucionalidad y consiguiente nulidad del art. 9 de la Ley de la Generalidad Valenciana 8/1986.

$2 .^{\circ}$ Declarar, asimismo, la inconstitucionalidad y consiguiente nulidad del inciso "y los que en su caso se establezcan reglamentariamente" del párrafo primero del art. 4.1, de la Ley 8/1986.

3..$^{\circ}$ Desestimar el recurso de inconstitucionalidad núm. 418/1987 en todo lo demás.

(Sentencia $n .^{\circ} 225 / 1993$, de 8 de julio. Pleno. BOE 2-8-1993. J. González Campos. Votos particulares formulados, el primero, por C. Viver PiSunyer, al que se adhieren $C$. de la Vega Benayas, V. Gimeno Sendra y $R$. Mendizábal Allende; y el segundo, por J. Gabaldón López).

2. Recurso de inconstitucionalidad núm. $884 / 87$ promovido por 57 Diputados del Congreso en relación con los arts. 1, 3, 4, 9, 10, 11, 17, 18 y 19 de la Ley del Parlamento de Cataluña 3/1987, de 9 de marzo, de Equipamientos Comerciales. El Tribunal Constitucional entiende que los preceptos impugnados suponen un lícito ejercicio de la potestad legislativa inherente a las competencias autonómicas sobre comercio interior y ordenación del territorio y urbanismo (arts. 12.1.5 y 1.1.9 del Estatuto Catalán), y ni traspasan los límites de las mismas impuestos por las normas constitucionales, ni puede estimarse que violen la libertad de empresa.

«Respecto del primer bloque, el art. 10 es el precepto nuclear. En efecto, en el 9.1 se dispone que para la apertura de un establecimiento comercial será indispensable obtener una licencia previa del Ayuntamiento correspondiente, cuyo otorgamiento dependerá del cumplimiento de una serie de condiciones reglamentariamente establecidas. Mas no basta con dicha licencia municipal, sino que es preceptivo, tanto para la apertura como para la ampliación, el informe favorable de una Comisión Territorial de Equipamientos Comerciales cuando se trate de establecimientos que reúnan ciertas características - determinada superficie edificada total o superficie neta de venta en relación con el número de habitantes de la población, mercados al por mayor... - y que se pueden llamar establecimientos comerciales de grandes dimensiones. Esta es la verdadera innovación normativa que la Ley catalana introduce. El art. 11 prevé los criterios que presidirán el informe motivado de dicha Comisión (...). Junto a este diseño normativo, el apartado $2 .^{\circ}$ del art. 9 habilita a la Administración autonómica para reglamentar los 
JURISPRUDENCIA

requisitos de los "distintos tipos genéricos de establecimientos comerciales", requisitos que deberán ser tenidos en cuenta por los Ayuntamientos para la concesión de licencias, debiendo especificarse en esos Reglamentos las características técnicas y "las condiciones de profesionalidad de los responsables, en función del grado de especialización de los establecimientos". En este contexto el art. 17 precisa que esos "tipos genéricos de establecimientos comerciales" de venta al público se caracterizarán por distintos elementos como son el surtido, la técnica de venta, la superficie, etc...; en el art. 18 se faculta al Reglamento para determinar las condiciones para el emplazamiento de ciertos establecimientos - al por mayor, de movimientos de mercancías...- y, finalmente, en el art. 19 de la Ley, se obliga al Reglamento a definir los diversos tipos genéricos de establecimientos, su denominación específica para evitar confusiones en los consumidores y los equipamientos necesarios.

Esta regulación, en su conjunto, es similar a la existente en otros ordenamientos europeos, y trata de cohonestar, desde el interés general que la Ley expresa y pondera, los intereses particulares y sectoriales de los empresarios y comerciantes, de los consumidores, y de los habitantes de las poblaciones afectadas por la apertura de establecimiento comercial, desde una planificación conjunta presidida por criterios comerciales y de urbanismo. $\mathbf{Y}$ no puede decirse que traspase límite constitucional alguno a la competencia autonómica sobre ordenación del comercio y defensa de los consumidores (art. 12.1.5 del Estatuto), ni que vulnere el derecho fundamental a la libertad de empresa o a la unidad del mercado nacional, ni que acabe por redundar en un inconstitucional obstáculo, por razones territoriales, a la libertad de establecimiento de las personas en todo el Estado. No importa aquí cuáles sean las opiniones divergentes sobre la conveniencia u oportunidad de su adopción por el legislador, cuestión que carece de relevancia en esta sede jurisdiccional a los efectos del control de constitucionalidad, ni tampoco los hipotéticos riesgos que en la demanda y en las alegaciones posteriores de los actores se denuncian acerca de que esta normativa sea - se dice- un caldo de cultivo de arbitrariedades y abusos.

Todo ello debe ser adecuadamente ponderado por el legislador autonómico en su libertad de configuración normativa y puede ser razonablemente opuesto por la minoría parlamentaria —como se afirma haber hecho- en una enmienda a la totalidad Proyecto de Ley presentado, pero no puede ser argumentado después como pretendido fundamento en una demanda de inconstitucionalidad. Por el contrario, las lesiones de derechos fundamentales o de la esfera respectiva de competencia de 
las Administraciones implicadas que se lleven por los actores a los procesos de constitucionalidad deben ser reales y efectivas, pero no basadas en simples juicios conjeturales o en afirmaciones de oportunidad política acerca de las normativas recurridas» (vid. f.j. $3^{\circ}{ }^{\circ}$.

Fallo: Desestimar el recurso de inconstitucionalidad.

(Sentencia $n .^{\circ} 227 / 1993$, de 9 de julio. Pleno. BOE 12-8-1993. C. de la Vega Benayas. Voto particular formulado por J. Gabaldón López).

3. Recurso de inconstitucionalidad núm. 1.862/87 promovido por el Presidente del Gobierno de la Nación en relación con los arts. 11, 12, 15.4, 16.4, 21.2.c) y 44.3 de la Ley del Parlamento de Galicia 10/1988, de 20 de julio, de ordenación del Comercio Interior de Galicia. El Tribunal Constitucional estima el recurso y declara la inconstitucionalidad de los mencionados artículos.

"Los arts. 11 y 12 L 10/1988 han venido a establecer un régimen de limitación y de intervención administrativo en cuanto a días y horas hábiles para el ejercicio del comercio en Galicia que, si bien se incardina, ratione materiae, en el ámbito genérico de la "ordenación del comercio" ex art. 20.1.4 EA Galicia, ha incurrido en contradicción patente con la medida liberalizadora introducida, con anterioridad a la adopción de estas normas, por el art. 5.1 RDL 2/1985, disposición ésta en la que, según lo dicho en el fundamento que antecede, se contiene una medida que se ha de tener por básica con arreglo a lo establecido en los arts. 149.1.13 CE y 30.1 EA Galicia, precepto este último que -según ya reseñamos - condiciona el ejercicio de las competencias allí atribuidas (la relativa al "comercio interior", entre otras) al respeto de "las bases y la ordenación de la actuación económica general" y en los términos -añade el precepto- de lo dispuesto, por lo que importa ahora, en el citado art. 149.1.13 CE. Conclusión de inconstitucionalidad tan clara no puede quedar empañada, en fin, por las argumentaciones expuestas, en defensa de estos preceptos, por las representaciones de la Comunidad Autónoma, argumentaciones a las que es preciso dar respuesta con las mismas consideraciones hechas en la STC 225/1993... La argumentación específica -no invocada en aquel proceso- de que la regla estatal aquí reconocida como básica (art. 5.1 RDL 2/1985) habría perdido hoy su fundamento o razón de ser no puede llevar, como bien se comprende, a desvirtuar esta conclusión, pues no corresponde a la jurisdicción constitucional, ciertamente, pronunciarse sobre la utilidad u oportunidad de las disposiciones legales y sí sólo sobre su acomodación 
JURISPRUDENCIA

a la CE y a las demás normas que integran el bloque de la constitucionalidad. El DL es fuente apta para el ejercicio de las competencias estatales ex. art. 149.1 (SsTC 29/1986 y 177/1990) y aunque la existencia efectiva de su presupuesto habilitante puede ser enjuiciada cuando así se impugna (SsTC 29/1982, 6/1983 y 29/1986), no cabe confundir tal hipotética tacha con la que aquí se ha articulado por el Parlamento de Galicia, relativa tan sólo, como decimos, a la mera pérdida sobrevenida de sentido de la norma en razón de un aducido cambio de circunstancias socio-económicas que corresponde apreciar al legislador, no a este Tribunal.

Cuanto antecede lleva, así, a la declaración de inconstitucionalidad de los arts. 11 y 12 L. 10/1988, declaración que ha de afectar, también, al inciso final núm. 1 del primero de dichos artículos, pasaje en el cual se advierte que la limitación de horarios comerciales allí establecida no ha de "perjudicar a los derechos reconocidos al trabajador por la legislación laboral vigente" dada su conexión con el resto de los preceptos, una vez que la norma en la que se inserta y de la que depende ha sido toda ella declarada inconstitucional.

Por las mismas razones ha de declararse parcialmente inconstitucional lo dispuesto en el art. 44.3 L. 10/1988, que tipifica como infracción "el incumplimiento de las normas relativas a horarios comerciales previstas en los artículos 11 y 12". Siendo cierta la conexión de inconstitucionalidad apreciable de la mención expresa de los arts. 11 y 12 y el vicio que a este último afecta, no lo es menos que suprimida por inválida tal remisión, la regla legal no es objetable en lo que se refiere a la calificación como infracción administrativa de otros eventuales incumplimientos de "normas relativas a horarios comerciales". Por ello, la declaración de inconstitucionalidad por conexión ha de limitarse sólo a la remisión que el art. 44.3 hace a los arts. 11 y 12 de la propia Ley" (vid. f.j. $3 .^{\circ}$ ).

«El otro grupo de preceptos impugnados viene constituido por los arts. 15.4, 16.4 y 21.2 c) L. 10/1988, incluidos, todos ellos, en el Tít. III de este texto legal ("Modalidades especiales de venta"). Establecen estas tres normas otros tantos límites temporales para la realización de específicas ofertas comerciales (ventas en rebajas, de saldos y de promoción) ya mediante la imposición de determinados lapsos de tiempo entre la verificación de varias del mismo tipo ya, en otro caso, a través del señalamiento de la duración, mínima y máxima, de la oferta. Del primer tipo son los límites establecidos en los arts. 15.4 y 16.4 , que disponen, respectivamente, que "entre la finalización de un período de rebajas y el 
comienzo de otro nuevo deben transcurrir por lo menos 135 días naturales" y que "entre la finalización de un período de saldos y el comienzo de otro nuevo deben transcurrir al menos 6 meses". Con un criterio diferente, el art. $21.2 \mathrm{c}$ ) establece que en el anuncio de una venta en promoción habrá de fijarse con claridad, entre otros extremos, "c) El período de vigencia de la promoción, que no podrá ser inferior a 2 días consecutivos ni superior a 30 días" (...) Lo que hemos de determinar es, por ello, si los preceptos impugnados se incardinan en la "legislación sobre la defensa de la competencia", de exclusiva titularidad estatal, o, por el contrario, en el ámbito de la "defensa del consumidor y del usuario", supuesto en el cual no sería aceptable el reproche de inconstitucionalidad expuesto en la demanda.

Este Tribunal ha tenido ya la ocasión de referirse a las dificultades existentes para deslindar, ante una regulación concreta, lo que sea propio del ámbito "defensa de los consumidores" y lo que corresponda, más bien, a la "defensa de la competencia" (STC 88/ 1986, FJ 4), dificultades que derivan, en parte, del propio concepto "defensa de los consumidores" ("amplio y de contornos imprecisos": SsTC 71/1982, FJ 1 y 15/1989, FJ 1) y también - ya en el ámbito que aquí más importa- del hecho de que ambas categorías - defensa de la competencia y defensa de los consumidores- remiten a otros tantos "aspectos de la ordenación del mercado", hasta el extremo de que, con frecuencia, "las medidas protectoras de la libre competencia funcionen también como garantía de los consumidores" y de que asimismo "medidas adoptadas para la protección de éstos no dejan de tener incidencia en el desarrollo de la libre competencia" (STC 88/1986, FJ 4). La relación entre uno y otro título competencial no es tanta, sin embargo, que no consienta su definición respectiva - por lo demás inexcusable-, y así dijimos en la última sentencia citada que la defensa de la competencia "se refiere a la regulación de la situación recíproca de las empresas productoras o distribuidoras en el mercado" y añadimos, en esa misma resolución, que la defensa de los consumidores "hace referencia a una situación distinta, en tanto que el consumidor aparece como destinatario de unos productos ofrecidos por las Empresas, productos cuyas condiciones de oferta se pretenden regular protegiendo, como indica el art. $51 \mathrm{CE}$, 'la seguridad, la salud y los legítimos intereses de los consumidores'” (FJ 4). A efectos de la caracterización competencial de una determinada norma lo relevante será, en suma, atender -como dijimos también entonces-al "objetivo predominante" del precepto y comprobar, así, si el mismo incide en el plano de la situación de las empresas en su actuación en el mercado en relación con otras empresas o si incide más bien en la actuación de la empresa frente a los consumidores. 
JURISPRUDENCIA

Con arreglo a estos criterios debemos considerar ahora si los preceptos impugnados se sitúan en uno u otro ámbito competencial, no sin antes desechar — por infundada y hasta artificiosa - la diferenciación que, con relevancia jurídico-constitucional, pretende establecer la representación de la Junta de Galicia entre "defensa de la libre competencia" -correspondiente, reconoce, al Estado- y prevención de la "competencia desleal", normativa, esta última, que podría - se diceser dictada por la Comunidad Autónoma. Semejante distinción competencial carece, en efecto, de todo apoyo en el bloque de la constitucionalidad, pues incluso aceptando que pudiera diferenciarse la regulación sobre competencia desleal, objeto hoy de una regulación propia (L. 3/1991), formalmente separada de la normativa general sobre defensa de la competencia (L.16/1989), en uno y otro caso se trata de una materia cuya legislación es de exclusiva titularidad estatal.

Es claro, a partir de cuanto antecede, que los arts. 15.4, 16.4 y $21.2 \mathrm{c}$ ) L. 10/1988 afectan, de manera predominante y directa, a lo que es propio de la defensa de la competencia y que al adoptarlos, por consiguiente, ha incurrido el Parlamento de Galicia en un notorio desbordamiento competencial. Sin perjuicio de lo que después se dirá respecto al último de estos preceptos legales, es claro que todos ellos limitan el libre ejercicio de la actividad mercantil a través del establecimiento de un marco temporal imperativo para el desarrollo de específicas modalidades de venta y que tales medidas no pueden entenderse sino como encaminadas a evitar que el equilibrio y la paritaria concurrencia entre empresarios en el mercado queden rotos por el abuso de un tipo de ofertas que, como éstas, aspiran a la preferente atracción de los consumidores. Es cierto, junto a ello, que la CA de Galicia puede regular, como declaramos en la STC 62/1991 (FJ 4), determinadas modalidades de venta y entre ellas, por ejemplo, las de "saldos y liquidaciones" allí consideradas, pues así lo permite su competencia en orden a la protección de los consumidores y usuarios; pero no lo es menos que cuando dicha reglamentación afecta al régimen de competencia entre los ofertantes y aspira, como aquí ocurre, a prevenir o evitar el excesivo recurso a este tipo de ventas especiales, las normas correspondientes no tienen otro encaje competencial que el de la propia defensa de la competencia, con la consecuencia de que su adopción, en mérito de lo dispuesto en el art. 30.1.4 EA Galicia, corresponde en exclusiva al Estado. A idéntica conclusión llegamos, por lo demás, en las SsTC 88/1986 y 148/1992, resoluciones, una y otra, que concluyeron con la anulación de normas autonómicas también limitativas ratione temporis del recurso a modalidades especiales de oferta mercantil similares a las reguladas en los preceptos aquí impugnados. A lo declarado al respecto en una y otra sentencia debemos remitirnos ahora. 
Se impone, pues, la declaración de inconstitucionalidad de los arts. 15.4 y 16.4 L 10/1988, declaración que ha de afectar también, por iguales razones, al último inciso art. 21.2 c) de la misma Ley, allí donde se dice que el período de vigencia de las ventas de promoción "no podrá ser inferior a 2 días consecutivos ni superior a 30 días". Anulado este inciso final del precepto, ningún reproche cabe hacer al enunciado con el que el mismo se abre, esto es, a la exigencia, en protección de los consumidores, de que en el anuncio de la venta en promoción figure con claridad su 'período de vigencia"' (vid. ff.jj. $4 .^{\circ}, 5 .^{\circ}$ y $6 .^{\circ}$ ).

Fallo: Estimar el recurso de inconstitucionalidad y, en consecuencia, declarar la inconstitucionalidad y consiguiente nulidad de los siguientes artículos de la Ley 10/1988, del Parlamento de Galicia, de la Ordenación del Comercio Interior: arts. 11, 12, 15.4, 16.4, 21.2.c), último inciso ("que no podrá ser inferior a dos días consecutivos ni superior a 30 días") y 44.3 , último inciso ("previstos en los arts. 11 y 12 ").

(Sentencia n. ${ }^{\circ}$ 228/1993, de 9 de julio. Pleno. BOE 12-8-1993. M. Rodríguez-Piñero y Bravo-Ferrer. Votos particulares formulados, el primero, por C. Viver Pi-Sunyer, al que se adhieren C. de la Vega Benayas, V. Gimeno Sendra y R. Mendizábal Allende; y el segundo, por J. Gabaldón López).

4. Recurso de inconstitucionalidad núm. 138/90 promovido por el Presidente del Gobierno de la Nación, contra los arts. 6.2, 15.3 c), 24, $25.1,30.2,35,38.2,39.3,56$ b), $k$ ), l) y r), y la disposición transitoria cuarta de la Ley de las Cortes de Aragón 9/1989, de 5 de octubre, de Ordenación de la Actividad Comercial en Aragón. El Tribunal Constitucional estima parcialmente el recurso y declara la inconstitucionalidad de los arts. 6.2, último inciso del art. 24, 30.2, 35, 39.3 a) y b) y 56 6) de la Ley de las Cortes de Aragón 9/1989

«El traslado de las anteriores conclusiones al examen del art. 6.2 de la Ley aragonesa conduce a la apreciación de su inconstitucionalidad. En efecto, aunque la Comunidad Autónoma de Aragón, de acuerdo con el art. 36.1,c) de su Estatuto, posee, "en el marco de la legislación básica del Estado y, en su caso, en los términos que la misma establezca", competencia de desarrollo legislativo y ejecución sobre la materia de comercio interior, en la que se inserta el subsector material de horarios comerciales, el precepto impugnado, sin embargo, se opone a la libertad proclamada en el art. 5.1 del Real Decreto-Ley 2/1985, toda vez que, frente a la completa autonomía otorgada a las empresas en todo el territorio nacional para fijar el horario de apertura y cierre de los establecimientos 
JURISPRUDENCIA

comerciales, así como los días y el número de horas de su actividad semanal, el referido precepto prevé la posibilidad, siquiera con carácter de excepción, de que dicha libertad sufra restricciones impuestas por el Departamento correspondiente de la Diputación General. Y dado que, conforme a lo anteriormente expuesto, el Estado, al dictar la norma básica liberalizadora, se amparó lícitamente en el título competencial del art. 149.1,13 CE, la oposición constatada supone un exceso del legislador autonómico en el ejercicio de la competencia estatutaria de que se ha hecho mención, lo que ha de conllevar la declaración de inconstitucionalidad de la disposición legal recurrida» (vid. f.j. $3^{\circ}$ ).

«El art. 39 regula la modalidad de ventas a pérdida, aquellas realizadas por el comerciante a precio inferior al de compra o de reposición, disponiendo su apartado 3 lo siguiente: "La fijación del precio de venta es libre. No podrán realizarse sistemáticamente ventas a un precio más bajo que el de adquisición en los casos siguientes: a) Cuando forme parte de una estrategia tendente a eliminar a un competidor o grupo de competidores del mercado, b) cuando tenga como fin último desprestigiar la imagen de un producto, c) cuando se haga con el fin de inducir a error a los compradores sobre el nivel de precios de otros productos de venta en el mismo establecimiento". Lo que aquí impugna el Abogado del Estado es el establecimiento de las restricciones transcritas, todas las cuales tienen como finalidad prevalente, a su juicio, no la protección del consumidor, sino la defensa de la competencia. Así es, sin duda, en los dos primeros supuestos. Ya dijimos en la STC 88/1986 (fundamento jurídico $8^{\circ}$ ) que "en cuanto la venta a pérdida puede incidir en perjuicio de otros comerciantes..., es claro que se está entrando en el ámbito de la libre concurrencia comercial, en su aspecto o perspectiva de igualdad y libertad de oportunidades en la estructura económica de libre competición...". Los subapartados a) y b) del art. 39.3 prohíben la práctica de la modalidad de venta a pérdida cuando la misma responda a finalidades contrarias a libre competencia. Por consiguiente, encajan claramente en la materia "defensa de la competencia", que es de titularidad estatal. No sucede lo propio, sin embargo, con la restricción prevista en el subapartado c), cuyo objetivo predominante consiste en la tutela del consumidor frente a una estrategia comercial tendente a confundirle respecto del efectivo nivel de precios del conjunto de los productos a la venta en un mismo establecimiento. Así, procede declarar la inconstitucionalidad del art. 39.3, apartados a) y b), por invasión de la competencia del Estado, únicamente en los supuestos indicados» (vid. f.j. 4. $^{\circ}$ ).

«Los arts. 24, segundo inciso, 30.2 y 35 de la Ley aragonesa se impugnan por invadir, a criterio del recurrente, el ámbito del Derecho 
mercantil y obligacional, de titularidad estatal $e x$ art. $149.1,6$ y $8 \mathrm{CE}$, pues dichos preceptos efectúan una regulación de obligaciones inter privatos.

Antes, sin embargo, de abordar el estudio de cada uno de los artículos recurridos, parece conveniente recordar que ya en la temprana STC 37/1981 declaró el Tribunal que sólo la legislación emanada de los órganos centrales del Estado puede regular la forma en que nacen y se extinguen los derechos y obligaciones a que el ejercicio de la actividad del empresario mercantil puede dar lugar y el contenido necesario de aquéllos y éstas (fundamento jurídico $3 .^{\circ}$ ). Por su parte, la STC 71/1982, a propósito de la regulación de lo que deba entenderse por cláusulas contractuales abusivas en perjuicio del consumidor, consideró como de pertenencia estatal la normación de las condiciones generales de contratación o de las distintas modalidades contractuales, e igualmente la de la responsabilidad por los daños originados en la adquisición, utilización o disfrute por los consumidores de bienes, medios o servicios, ya que el régimen de unas y otras materias, incardinado en la legislación civil (art. 149.1,8 CE), debe ser uno y el mismo para todo el territorio del Estado (fundamentos jurídicos 14 y 19). No es, claro está, que a las normas autonómicas no les quepa disciplinar determinados tipos de venta o articular dispositivos preventivos o correctores de los eventuales abusos a que ciertos contratos puedan conducir. De lo que se trata es de que a través de tales normas no se produzca un novum en el contenido contractual o, en otros términos, de que no se introduzcan derechos ni obligaciones en el marco de las relaciones contractuales privadas (STC 88/1986, fundamento jurídico $5 .^{\circ}$ ). Por último, aun cuando las normas autonómicas persigan, mediante el reforzamiento de las obligaciones del vendedor, la protección del consumidor y del usuario, "la determinación del contenido de los contratos y de las acciones por incumplimiento, saneamiento o resolución se insertan dentro de la competencia estatal exclusiva atribuida al Estado por los arts. 149.1, 6 y 8 CE" [STC 62/1991, fundamento jurídico $4 .^{\circ} \mathrm{e}$ )]

De los citados pronunciamientos se desprende con total nitidez, por consiguiente, que la regulación autonómica de las diferentes modalidades de venta para proteger los derechos de los consumidores y reequilibrar la posición de éstos en el mercado sobre todo cuando la adquisición de bienes tiene lugar fuera de los establecimientos comerciales o en otras circunstancias especiales debe ceñirse al espacio de las relaciones jurídico-públicas, impidiendo o limitando las prácticas lesivas de los intereses tutelados, definiendo las conductas exigibles en congruencia con tales intereses y estableciendo las sanciones administrativas pertinentes, pero sin determinar consecuencia alguna en el ámbito de las relaciones jurídico-privadas ni imponer un contenido contractual determinado 
JURISPRUDENCIA

pretendidamente acorde con el fin protector perseguido, ya que eso corresponde al acervo competencial del Estado ex art. 149.1,6 y 8 CE.

Pues bien: trasladando este criterio delimitador al examen de los preceptos de la Ley aragonesa referidos, cabe concluir los siguiente:

El segundo inciso del art. 24 ("en tales supuestos de ventas con remisión al comprador de bienes u ofertas de servicios con el fin de provocar su tácito consentimiento, la persona a quien van dirigidos los bienes, productos y servicios no contrae ninguna obligación de pago, depósito o restitución de los objetos o documentos enviados") debe reputarse inconstitucional desde la perspectiva del orden competencial, puesto que, con independencia de que otras normas generales del ordenamiento lo conviertan en innecesario, la determinación de los supuestos de exención de las obligaciones civiles o mercantiles y, más en general, de las consecuencias inter privatos del incumplimiento de las prohibiciones legales en relación, en este caso, con el ejercicio de una modalidad de venta condicionada expresamente excluida por la Ley autonómica corresponde indudablemente al legislador estatal, en virtud de los títulos competenciales invocados por el recurrente. Tal se declara, además, para una hipótesis similar a la ahora contemplada, en la STC $88 / 1986$, fundamento jurídico $8 .{ }^{\circ} \mathrm{C}$ ).

En cuanto al art. 30.2, establece que "en todos los casos de venta domiciliaria el comprador dispondrá de un período de siete días para rescindir el compromiso de compra, con el único requisito de comunicárselo de forma fehaciente al comerciante y con los efectos de devolución de la cosa y del precio". Esta previsión, sin embargo, supone un exceso del Parlamento autonómico en el desenvolvimiento de la competencia sobre defensa del consumidor y del usuario [art. 36.1,c) del Estatuto], ya que claramente incide en el contenido de los contratos, lo que, como se ha dicho, únicamente cumple regular al Estado, de acuerdo con el art. 149.1,6 y 8 CE [STC 62/1991, fundamento jurídico $4 .^{\circ}$ b) y e)]. Precisamente el Estado, para incorporar al Derecho español la Directiva del Consejo de las Comunidades Europeas 85/577, de 20 de diciembre, sobre protección de los consumidores en los contratos negociados fuera de los establecimientos mercantiles, ha tenido que utilizar la forma de ley, se dice en la Exposición de Motivos de la Ley 26/1991, de 21 de noviembre, dado que en la misma "se establecen preceptos que afectan y modulan el régimen del perfeccionamiento y de la eficacia de los contratos, materias éstas que aparecen reguladas en el Código Civil", preceptos entre los que se halla el art. 5, que reconoce al consumidor el derecho de poder revocar su declaración de voluntad, sin necesidad de 
alegar causa alguna, hasta pasados siete días contados desde la recepción del producto adquirido.

El art. 35, por último, según el cual "serán responsables solidarios por las irregularidades derivadas de la venta automática el titular del establecimiento donde se encuentre ubicada la máquina vendedora y el titular de la explotación comercial de la misma", también concierne a una materia de titularidad estatal, como es la referente al carácter de la responsabilidad obligacional, como ya se ha declarado respecto a un supuesto similar en la STC 71/1982, fundamento jurídico 17, pues "el régimen de la responsabilidad debe ser uno y el mismo para todo el territorio del Estado". En consecuencia, este precepto y los anteriormente analizados en el presente fundamento jurídico deben ser declarados inconstitucionales» (vid. f.j.5. ${ }^{\circ}$ ).

«El art. 56 de la Ley aragonesa tipifica como infracciones administrativas en materia de actividad comercial una serie de conductas contrarias a lo establecido en las disposiciones anteriores del mismo cuerpo legal. El Abogado del Estado impugna, por conexión, los apartados b), k), l) y r).

El apartado b), referente al "incumplimiento de la normativa excepcional prevista en el art. 6", es decir, la relativa a la limitación de los horarios comerciales debe, en efecto, declararse inconstitucional, dada su conexión con el art. 6.2 de la Ley.

El apartado k), atinente a "la práctica de ventas por inercia, prohibidas por el art. 24" es, cambio, constitucionalmente legítimo, congruentemente con la licitud de la regulación del primer inciso del precepto con el que se corresponde.

El apartado 1), concerniente al "desarrollo de las ventas en cadena, prohibidas por el art. 25" resulta conforme con la Constitución, pues ningún reproche merece el precepto con el que se conecta.

Por último, el apartado r), relativo al "incumplimiento de los requisitos que para las ventas a pérdidas se contienen en el art. 39", sólo puede declararse inconstitucional por conexión con las letras a) y b) del art. 39, lo que implica que dicho apartado, redactado en términos más amplios, no cabe que sea declarado nulo" (vid. f.j. $7^{\circ}$ ).

Fallo: Estimar parcialmente el recurso de inconstitucionalidad y, en consecuencia: 
JURISPRUDENCIA

$1 .^{\circ}$ Declarar la inconstitucionalidad y consiguiente nulidad de los artículos 6.2, 24 (último inciso: "en tales supuestos la persona a quien van dirigidos los bienes, productos y servicios no contrae ninguna obligación de pago, depósito o restitución de los objetos o documentación"), $30.2,35,39.3$ a) y b) y 56 6) de la Ley de las Cortes de Aragón 9/1989, de 5 de octubre, de Ordenación de la Actividad Comercial en Aragón.

2. ${ }^{\circ}$ Declarar que el art. $56 \mathrm{r}$ ) de dicha Ley es inconstitucional sólo en su conexión con los apartados a) y b) del art. 39.3.

3. Desestimar el recurso en todo lo demás.

(Sentencia n. ${ }^{\circ}$ 264/1993, de 22 de julio. Pleno. BOE 18-8-1993. J. González Campos. Voto particular formulado por $C$. Viver Pi-Sunyer, al que se adhieren C. de la Vega Benayas, J. Gabaldón López y R. de Mendizábal Allende).

\section{C) Entidades de crédito}

1. Conflicto positivo de competencia núm. 813/86, promovido por el Gobierno de la Nación en relación con el artículo 3.2 y los apartados a) y b) del artículo 6.1 del Decreto 8/1986, de 10 de febrero, del Consejo de la Generalidad Valenciana, por el que se desarrolla la Ley 11/1985, de 25 de octubre de Cooperativas de la Comunidad Valenciana, en materia de Cooperativas de Crédito. El Tribunal constitucional entiende que los citados preceptos invaden la competencia estatal atribuida por el apartado 11 del párrafo 1, art. 149 de la Constitución relativa a las «bases de la ordenación del crédito».

«El art. 3.2 del referido Decreto autonómico, dispone que "no obstante lo dispuesto en el número anterior, se podrán realizar las citadas operaciones activas con terceros no socios siempre que el conjunto de las concertadas no rebase el porcentaje del $10 \%$ de los recursos ajenos, en el caso de Cooperativas de primer grado, o del $20 \%$ tratándose de Cooperativas de segundo grado" y "en todo caso, los resultados netos de estas operaciones con terceros no socios se destinarán al Fondo de Reserva Obligatoria". Es ésta una previsión que para el promotor del conflicto quedaría enmarcada por un contenido en la materia "legislación mercantil" y, a la vez, invadiría la competencia estatal para fijar las "bases de la ordenación del crédito".

El art. 6, en sus apartados a) y b), atribuye a la Consejería de Economía y Hacienda de la Comunidad Valenciana el ejercicio de la 
competencia a fin de "conceder autorización para poder rebasar los límites que, en cuanto a la concentración de riesgos con una persona o un grupo, se establezcan reglamentariamente, así como la determinación de las garantías y condiciones que amparan la asunción de este mayor riesgo". Y el apartado b), para "autorizar que la cartera de valores de renta variable, con independencia de los computados en los coeficientes de inversión obligatoria, más las inmovilizaciones en edificios y mobiliario, pueda rebasar la cifra de recursos propios". Con estos preceptos, se aduce, quedan encomendadas a un órgano de la Administración autonómica competencias que corresponden al Estado según lo dispuesto en el art. 149.1,11 de la CE" (vid. f.j. 1. ${ }^{\circ}$ ).

"A las cooperativas de crédito "la especialidad dimanante de su actividad crediticia las ha asimilado y terminado por incorporar al género de las entidades o establecimientos de crédito".

Por ello, la competencia exclusiva en materia de cooperativas de crédito "debe conjugarse con la competencia también exclusiva del Estado para fijar las bases de la ordenación del crédito". Y desde esta perspectiva exclusiva (que es la que únicamente interesa en relación con el precepto controvertido), ha de partirse, como en aquella Sentencia, de que la competencia específica de la Comunidad Valenciana no sólo sobre cooperativas de crédito, sino sobre la "ordenación del crédito, banca y seguros" tiene lugar "en el marco de la legislación básica del Estado".

Por consiguiente (respecto a la impugnación del art. 3.2 del Decreto autonómico), en lo relativo a estas operaciones con terceros la controversia se dilucidará en relación con el carácter (básico o no) que corresponda atribuir al precepto. Y carácter básico tiene, en la Ley 13/1989, de Cooperativas de Crédito, su art. 4, según el cual las Cooperativas podrán realizar toda clase de operaciones activas con terceros... no podrán alcanzar el 50\% de los recursos totales de la entidad". Punto sobre el que también se pronuncia la anterior STC 155/1993, fundamento jurídico $5 .^{\circ}$, según la cual "la determinación de si las Cooperativas de Crédito pueden o no concertar esas operaciones (con terceros no socios) es una decisión a la que, por su carácter íntimamente relacionado con la configuración y definición de dichas entidades, debe atribuirse carácter básico de la ordenación del sector crediticio y que, por ello mismo, resulta radicalmente ajena al ámbito competencial de las Comunidades Autónomas. Siendo las Cooperativas de Crédito instituciones de crédito, la definición de las mismas (y por tanto, la determinación de un aspecto estructural de esa definición cual es la posibilidad o no de realizar operaciones 
activas con terceros) en cuanto acota la materia a regular y sirve así como elemento básico delimitador de competencias, resulta sin duda un aspecto esencial de la ordenación del crédito".

Más aún, en relación con la limitación establecida respecto de esas operaciones, allí mismo se interpretó que "correspondiendo al Estado en el ejercicio de la competencia que le atribuye el art. 149.1,11 CE excepcionar o modular el principio mutualista que tradicionalmente ha caracterizado a las Cooperativas de Crédito y las ha diferenciado de otras entidades y sociedades, dando entrada a que en sus funciones pueda incluirse la realización de operaciones activas con terceros o socios, ninguna objeción en estrictos términos constitucionales puede oponerse a los términos concretos y precisos en que esa excepción, o cuando menos modulación, haya quedado establecida. De ahí que la limitación que incorpora el art. 4.2, párrafo primero, impugnado, no vulnere las alegadas competencias de la Generalidad de Cataluña".

Cierto es que el precepto que aquí se cuestiona difiere un tanto del que fue objeto de la doctrina expuesta y pudiera acaso dar pie a su consideración como norma de desarrollo permitida a la Comunidad Autónoma. No es ésta, sin embargo, una interpretación aceptable. En primer término, porque la norma básica estatal (límite máximo de las operaciones activas con terceros) establece un tope genérico para este tipo de operaciones, resultado de una evolución legal cada vez más permisiva como consecuencia sin duda del fin de fomento de estas entidades (art. 129.2 CE) y tendente, por ello, precisamente, a que dicho límite, en cuanto máximo, constituya una norma dentro de la cual pueda moverse con mayor libertad la decisión de cada entidad y no la competencia de desarrollo limitativa de la Comunidad Autónoma.

Así viene a corroborarlo, por otra parte, la misma evolución legislativa, de la cual resulta un propósito de la normativa autonómica, de no atenerse a la legislación del Estado. Así, en su escrito de contestación a la demanda, alega la relación de este artículo de su Reglamento con el proyecto de Ley General de Cooperativas (aprobado entonces por el Congreso el 18 de marzo de 1986) que, en su Disposición transitoria, establece que las operaciones activas con terceros podrán realizarse "hasta un máximo de $15 \%$ de sus recursos totales", preceptos finalmente incluidos en la Ley 3/1987, de 2 de abril, especificando que "los resultados netos obtenidos en estas operaciones se reflejarán en contabilidad separada, de manera clara e inequívoca, y se destinarán al Fondo de Reserva obligatoria (Disposición transitoria sexta, 3). 
Tanto respecto de aquella Ley como del citado art. 4.2 de la vigente, lo que el precepto impugnado lleva a cabo es una regulación respetando solamente la prescripción de que exista un límite máximo, pero la articula de modo diferente, no simplemente limitativo. Así, la norma básica establece: un límite para estas operaciones; que éste sea un tope máximo y, por tanto, que dentro del mismo cada entidad pueda actuar libremente; que se refiera los "recursos totales" de la entidad y que no alcance el $50 \%$ de éstos. Sin embargo, el artículo impugnado sólo coincide en el establecimiento de un límite máximo, pero éste se refiere no a los "recursos totales" sino a los "recursos ajenos", lo cual es concepto distinto y origina una magnitud diferente; y el porcentaje no es único, sino doble: $10 \%$ para las Cooperativas de primer grado y $20 \%$ las de segundo grado. No se trata, pues, de una norma de desarrollo sino de una norma distinta y cuyos mandatos no permiten siquiera conocer si se mueve o no dentro de los límites resultantes de la norma básica.

Los apartados a) y b) del art. 6 del Decreto de la Generalidad Valenciana, a juicio del Abogado del Estado, contradicen, asimismo, el orden constitucional de competencia dispuesto en el art. 149.1,11 CE, porque la autorización para rebasar los límites que en cuanto a concentración de riesgos con una persona o grupo reglamentariamente se establezcan, así como aquella otra autorización para que la cartera de valores de renta variable pueda superar la cifra de recursos propios, aun siendo actos de ejecución, no pueden disociarse de lo básico en la materia crediticia y corresponde, por ello, su autorización a la Administración estatal.

Esos preceptos reconocen, como antes decimos, a la Consejería de Economía y Hacienda de la Generalidad Valenciana una potestad autorizatoria que guarda directa relación con las condiciones de garantía y solvencia y cumplimiento de las normas de control y disciplina que, en su condición de establecimiento de crédito o entidades de depósito, también las Cooperativas de Crédito deben observar (Real Decreto Legislativo 1.298/ 1986, de 28 de junio y Ley de 13/1985, de 25 de mayo, art. 6 , respectivamente).

La citada STC 155/1993 señaló que debía considerarse norma básica el precepto que ordena destinar al fondo de reserva obligado el $50 \%$, como mínimo, de los beneficios del ejercicio, porque, como antes señalábamos, "razones directamente conectadas a la política de solvencia de las Cooperativas de Crédito avalan tal condición de norma básica, de acuerdo con la doctrina que, a propósito de las entidades de depósito general, fijamos, entre otras, en las SsTC 135/1992 y 178/1992". Esta consideración debe llevar, en este caso, a igual conclusión, puesto que 
JURISPRUDENCLA

se trata de una autorización administrativa para rebasar los límites de riesgo reglamentariamente establecidos, cuestión que de modo directo afecta a su solvencia. Por otra parte, esa autorización se configura como una dispensa o excepción de una norma básica (la contenida en el art. 9.1 de la ley 13/1985, de 28 de mayo, a la que ya nos referimos en la STC $135 / 1992$, fundamentos jurídicos $3 .^{\circ}$ y $5 .^{\circ}$ ) y vinculada directamente a la política de solvencia de las Cooperativas de Crédito.

Y aunque por su carácter propio pudiera considerarse esta autorización como acto de ejecución, ello no la excluiría del ámbito de las bases de ordenación del crédito reservadas a la competencia estatal, pues como ya hemos señalado con cierta profusión entre las más recientes, en las citadas SsTC 135/1992 y 178/1992, la competencia del Estado sobre dichas bases puede alcanzar y englobar también aspectos puramente ejecutivos cuando se encuentren afectados directamente intereses supraautonómicos, se trate de decisiones y actuaciones que trascienden del caso particular y de las concretas situaciones afectadas dada la interdependencia de éstas en todo el territorio nacional o, en fin, cuando el acto de ejecución comporte, por necesidad intrínseca de la materia, márgenes tan amplios de discrecionalidad que sólo pueda ser adoptado por instancias que tengan a su cuidado intereses peculiares distintos a los puramente generales. Y tampoco puede desconocerse que, además, en relación a esas intervenciones estatales de alcance estrictamente ejecutivo en la materia crediticia, el Banco de España, como asesor del Gobierno de la Nación y ejecutor inmediato de su política monetaria y crediticia, ocupa un lugar preeminente dada su especialización técnica de manera que la ordenación básica del crédito corresponde no sólo a los Cuerpos Colegisladores y al Gobierno sino también, en un nivel operativo, al Banco de España (SsTC 135/1992, fundamento jurídico $3 .^{\circ}$ y $178 / 1992$, fundamento jurídico $\left.2 .^{\circ}\right)$.

En cuanto al apartado b) del mismo art. 6.1, debe señalarse que el art. 10.2 de la Ley 13/1985 atribuye expresamente al Banco de España la potestad de autorizar a las entidades de depósito y, por serlo, a las Cooperativas de Crédito nuevas inversiones que excedan de los límites máximos que en función de sus recursos propios puedan imponerse. De este modo, y sin necesidad ya de mayores consideraciones dado el carácter básico de la norma estatal (STC 135/1992, fundamentos jurídi$\cos 3 .^{\circ}$ y $5 .^{\circ}$ ), la conclusión no puede ser otra que la de estimar la pretensión deducida por el Abogado del Estado, al atribuirse la Comunidad Autónoma, también aquí, una potestad ajena a su ámbito de competencias" (vid. ff.jj. $4 .^{\circ}$ y $5 .^{\circ}$ ). 
Fallo: Declarar que las competencias controvertidas a que se refieren los arts. 3.2 y los apartados a) y b) del artículo 6.1 del Decreto 8/1986, de 10 de febrero, del Consejo de la Generalidad Valenciana, corresponden al Estado y, en consecuencia se declara la nulidad de dichos preceptos.

(Sentencia.$^{\circ}$ 204/1993, de 17 de junio. Pleno. BOE 19-7-1993. J. Gabaldón López. Voto particular formulado por C. Viver Pi-Sunyer, al que se adhiere V. Gimeno Sendra).

\section{D) Telecomunicaciones}

1. Conflictos positivos de competencia acumulados núms. 1.108/86 y 624/1987, planteados por el Gobierno Vasco contra el Real Decreto 1.201/1986, de 6 de junio, por el que se regula el procedimiento para la obtención de autorizaciones administrativas para la instalación de funcionamiento de las instalaciones radioeléctricas receptoras de programas de televisión transmitidos por satélite de comunicaciones del servicio fijo por satélite, y frente a la Orden de 30 de diciembre de 1986, por la que se desarrolla el Decreto precitado. El Tribunal Constitucional declara que las competencias ejercidas a través de dichas normas corresponden al Estado

"La normativa en estos conflictos discutida atiende claramente a aspectos estrictamente técnicos de la comunicación por ondas radioeléctricas y, en concreto, relativos a la recepción por emisoras terrenas de programas de televisión transmitidos en servicio fijo por satélite, y que esta regulación y la autorización administrativa que se exige cuya oportunidad no corresponde al Tribunal Constitucional enjuiciar tiene por finalidad sustancial la homologación y normalización de los equipos e instalaciones y la evitación de interferencias. Prevalece pues, el título competencial del Estado para ordenar de manera exclusiva la telecomunicación y la radiocomunicación (art. 149.1,21 CE) sobre los aspectos propios de la difusión y recepción de programas de televisión, preferentemente conexos a las libertades y derechos fundamentales que se ejercen a través de los medios de comunicación social y a los que atienden las competencias autonómicas reflejadas en el art. 149.1,27 CE

Enjuiciadas, pues, ambas disposiciones desde la medida o canon de constitucionalidad que el citado art.149.1,21 CE, entraña, la solución del litigo carace de mayores complejidades, pues, prima facie la totalidad de los preceptos de estas disposiciones responden al afán de ordenar un 
JURISPRUDENCIA

procedimiento para el otorgamiento de autorizaciones administrativas para la instalación de estaciones receptoras; y debe bastar ahora, por tanto, con constatar si los concretos artículos discutidos desbordan esta finalidad introduciéndose en el ámbito propio del art. 149.1,27 CE.

Si bien en los encabezamientos de ambas demandas de conflicto parece impugnarse la totalidad del Decreto y de la Orden discutidos, en los suplicos y en los razonamientos contenidos en las fundamentaciones de las demandas son sólo unos cuantos artículos de ambas disposiciones los que realmente se recurren. En concreto: los arts. 4, 5 y 7 del Decreto, y los arts. 2, 5, 7 y 8 de la Orden. Habrá, pues, de restringirse al enjuiciamiento de esos concretos preceptos.

$\mathrm{El}$ art. 4 del Decreto establece que la instalación y el funcionamiento de una estación terrena receptora deberá estar amparada por la autorización administrativa expedida por la Dirección General de Telecomunicación. Se trata del ejercicio de una potestad de ejecución que en razón de la materia sobre la cual se concede la autorización administrativa, que atiende a aspectos técnicos del dominio público radioeléctrico, se sitúa en la competencia estatal sobre radiocomunicación.

$\mathrm{El}$ art. 5 del Decreto se limita a prever que las solicitudes pueden presentarse bien directamente ante la citada Dirección General o por medio de las Jefaturas Provinciales de Comunicaciones en la forma prevista en el art. 66 de la vieja Ley de Procedimiento Administrativo; a la par que se contempla la documentación que es preciso acompañar a la solicitud, muy especialmente el proyecto de instalación y el pliego de condiciones técnicas redactado por ciertos peritos en la materia. Estos extremos de la ordenación del procedimiento entran también en el terreno del art. 149.1,21 CE, como consecuencia inevitable de que en ese título competencial encuentre cobertura la autorización administrativa cuya forma de solicitud, requisitos y lugar de presentación aquí se regula.

En el art. 7 se establece una norma meramente instrumental de la autorización administrativa que el art. 4 del Decreto exige: el dato obvio de que dicha autorización, en cuanto acto de verificación reglado, se expedirá a la vista de la documentación aportada.

Dentro del artículo 8 del Decreto, se contempla una limitación a la autorización administrativa en su caso concedida: se faculta a los titulares únicamente para la recepción de programas de televisión, con 
expresa exclusión de cualquier otra clase de comunicaciones, así como de la divulgación del contenido u otro uso no amparado por la autorización. Un mandato que debe ponerse en conexión con la Disposición Adicional primera del mismo Decreto donde se afirma que de conformidad con la Ley 46/1983, de 26 de diciembre, reguladora del tercer canal de televisión, el Decreto discutido no habilita para la difusión, distribución o transmisión de señales captadas por una estación terrena fuera del ámbito comprendido en la autorización administrativa; y con la propia Disposición Adicional primera de la citada Ley reguladora del tercer canal que reserva en exclusiva a RTVE para todo el territorio español los sistemas de emisión y transmisión mediante cable, satélite, o cualquier otro procedimiento de difusión destinado mediata o inmediatamente al público; un precepto cuyo alcance analizamos en las SsTC 21/1988 (fundamentos jurídicos $2 .^{\circ}$ y $3 .^{\circ}$ ) y $154 / 1989$ (fundamento jurídico $\left.4 .^{\circ}\right)$.

La Orden que viene a desarrollar el Decreto impugnado prescribe en su art. 2 que las solicitudes se ajusten a un modelo que figura en un Anexo a la Orden. Se trata claramente de un precepto meramente auxiliar e instrumental de la exigencia de autorización administrativa y que, por ello, permanece dentro de la competencia exclusiva que el Estado posee para ordenar la radiocomunicación.

El art. 5 de la Orden, en sus tres apartados, diseña un procedimiento que sustancialmente consiste en una aprobación inicial del proyecto técnico presentado con la solicitud, y la necesidad de presentar luego, en el plazo de un año, una certificación de haber construido la emisora terrena conforme al proyecto, para alcanzar la aprobación definitiva; se prevé también la posibilidad de que la Dirección General de Telecomunicaciones decreta la caducidad de la autorización administrativa por diversas causas, entre las que se encuentra la existencia de "Acuerdos internacionales que obliguen a España o de disposiciones de ámbito nacional relativas a la reestructuración de los servicios que afecten a esta clase de Estaciones" (apartado $3 .^{\circ}$ ). Unos extremos encaminados al otorgamiento o revocación de la autorización administrativa y, por ello, igualmente ubidados dentro de la competencia estatal ex. art. 149.1,21 CE.

Las facultades estatales de inspección de las instalaciones se recogen en el art. 7. Pero siendo las facultades de inspección de naturaleza ejecutiva y accidentales respecto de las competencias sustantivas, según una muy reiterada y constante jurisprudencia constitucional (SsTC $32 / 1983$, fundamentos jurídicos $3 .^{\circ}$ y $4 .^{\circ} ; 113 / 1983$, fundamento jurídico $3 .^{\circ} ; 54 / 1990$, fundamento jurídico $3 .^{\circ}$; etc...), y teniendo el Estado potes- 
JURISPRUDENCIA

tades de toda clase en materia de radiocomunicación tanto normativas como ejecutivas, nada puede reprocharse a este precepto.

Por último, en el art. 8 se establece la obligación de que los titulares de estaciones terrenas antes de la entrada en vigor del Decreto declaren su existencia a la Dirección General de Telecomunicaciones en un plazo de tres meses desde la entrada en vigor de la Orden. Un precepto que intenta respetar las situaciones creadas antes de la ordenación de este nuevo fenómeno, al tiempo que busca centralizar en la mencionada Dirección General la información necesaria sobre las estaciones receptoras existentes con el fin de permitir una adecuada ordenación del espectro radioeléctrico, evitando interferencias entre los usuarios.

En suma, las dos disposiciones impugnadas y, en particular, los concretos preceptos que en los petita de las demandas se impugnan suponen una regulación que debe estimarse como un ejercicio de la competencia exclusiva del Estado para ordenar los aspectos técnicos del dominio público radioeléctrico (art. 149.1,21 CE); todo ello sin perjuicio de que como ya se ha dicho en la actualidad dicha normativa haya perdido gran parte de su eficacia normativa, restringiéndose su ámbito de aplicación, y de que se encuentre aquejada de una clara transitoriedad que puede conducir a su desaparición" (vid. ff.jj. $4 .^{\circ}, 5^{\circ}, 6 .^{\circ}$ y $\left.7 .^{\circ}\right)$.

Fallo: Declarar que la competencia ejercida a través del RD 1.201/1986, de 6 de junio, y de la Orden de 30 de diciembre de 1986, corresponde al Estado.

(Sentencia $n .^{\circ}$ 244/1993, de 15 de julio. Pleno. BOE 12-8-1993. A. Rodríguez Bereijo. Voto particular formulado por L. López Guerra, y al que se adhieren V. Gimeno Sendra, J. Gabaldón López, R. de Mendizábal Allende y $C$. Viver Pi-Sunyer). 
